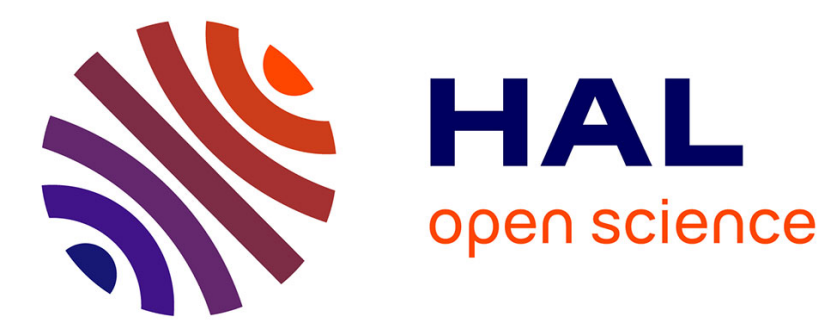

\title{
Determining the porosity and water impregnation in irradiated graphite
}

\author{
J. Comte, C. Guy, L. Gosmain, S. Parraud
}

\section{To cite this version:}

J. Comte, C. Guy, L. Gosmain, S. Parraud. Determining the porosity and water impregnation in irradiated graphite. Journal of Nuclear Materials, 2018, 528, pp.151816. 10.1016/j.jnucmat.2019.151816 . cea-02339842

\section{HAL Id: cea-02339842 https://hal-cea.archives-ouvertes.fr/cea-02339842}

Submitted on 16 Mar 2020

HAL is a multi-disciplinary open access archive for the deposit and dissemination of scientific research documents, whether they are published or not. The documents may come from teaching and research institutions in France or abroad, or from public or private research centers.
L'archive ouverte pluridisciplinaire HAL, est destinée au dépôt et à la diffusion de documents scientifiques de niveau recherche, publiés ou non, émanant des établissements d'enseignement et de recherche français ou étrangers, des laboratoires publics ou privés. 


\section{Determining the porosity and water impregnation in irradiated graphite}

1 Names of the authors: J. Comte ${ }^{1}$, C. Guy ${ }^{1}$, L. Gosmain ${ }^{2,}$ S. Parraud ${ }^{3}$

2 Title:

Affiliation(s) and address(es) of the author(s):

$3{ }^{1}$ CEA, DEN, DEC, SA3E, LARC Commissariat à l'Énergie Atomique et aux 4 Énergies Alternatives (CEA), Direction de l'énergie Nucléaire, Département d'études 5 des combustibles, Service d'Analyses, d'Elaboration, d'Expérimentations et 6 d'Examens des combustibles, Laboratoire d'Analyses Radiochimiques et Chimiques, 7 Centre de Cadarache, Bâtiment 152, F-13108 Saint Paul lez Durance, France

8

${ }^{2}$ CEA, DEN, DDCC, ISN Commissariat à l'Énergie Atomique et aux Énergies Alternatives (CEA), Direction de l'énergie Nucléaire, Direction du Démantèlement pour les Centres Civil, Installations de Service Nucléaire, centre de Saclay, Bâtiment 121, F-91191 Gif-sur-Yvette cedex, France

${ }^{3}$ CEA, DEN, DSN, SEEC, LECD Commissariat à l'Énergie Atomique et aux Énergies Alternatives (CEA), Direction de l'énergie Nucléaire, Département de Services Nucléaires, Service d'Exploitation, d'Expertise et de Caractérisation, Laboratoire d'Expertise et de Caractérisation Destructive, Centre de Cadarache, Bâtiment 326, F-13108 Saint Paul lez Durance, France 


\title{
Journal of Nuclear Materials
}

\begin{abstract}
Impurities in nuclear graphite can become neutron-activated during operation, generating radionuclides and leading to modifications in the microstructure of the graphite due to fast neutrons. The long-term disposal of nuclear graphite waste requires collecting data on the behaviour of long-lived radionuclides in disposal conditions (water-saturated). The release of radionuclides in solution depends on a number of physicochemical processes such as water ingress into the graphite structure (radionuclides sites), as well as the solubilisation and transport of radionuclides in solution through the graphite pores. Analysis of the impregnation (impregnation speed, impregnation rate) of water in the porous graphite environment represents one of the main parameters that will greatly influence the physicochemical processes controlling the release of radionuclides in solution. For this reason, the impregnation of irradiated samples from the G2 and St Laurent A2 (SLA2) gas-cooled graphite-moderated reactors was studied, as was the distribution of the porosity. Results show that the geometric density of the samples decreases after irradiation, which is expressed as an increase in the total porosity or more precisely in the open porosity. This means that irradiated graphite is mainly a macroporous solid. Nuclear graphite becomes a more hydrophobic material with its open porosity filled by water in just a few days. This is due to the presence of functional groups on the pore surface.
\end{abstract}

\section{Keywords}

Graphite, nuclear waste, water uptake, radionuclides, porosity, UNGG 


\section{Journal of Nuclear Materials}

The decommissioning of graphite-moderated nuclear reactors will generate about 230,000 tonnes of graphite waste worldwide [1]. In France, the Commissariat à l'Énergie Atomique et aux Énergies Alternatives (CEA) and Electricité de France (EDF) operated 9 gas-cooled graphite-moderated reactors (UNGG) which have all been shut down for at least 20 years now. They were graphite-moderated and fuelled with natural metallic uranium. The decommissioning of these reactors will generate about 23,000 tonnes of irradiated-graphite (igraphite), representing around $81,000 \mathrm{~m}^{3}$ of conditioned waste in cementitious packages [2]. Some of the impurities contained in the nuclear graphite became neutron-activated during operation, giving rise to numerous radionuclides such as ${ }^{36} \mathrm{Cl},{ }^{14} \mathrm{C},{ }^{3} \mathrm{H}$, etc.

According to the French 2006 Act on the sustainable management of radioactive materials and waste passed by the French parliament [3], a dedicated shallow disposal concept was chosen as the reference solution for the long-term management of French graphite waste. In this concept of disposal site, the waste will be at term in contact with underground water. Thus, it is very important to know and understand underwater graphite behavior in terms of water uptake and hence of radionuclide release. In order to design the best long-term management option for irradiated -graphite, the producers (the CEA and EDF) carried out experimental studies in collaboration with the French national waste management agency (Andra) to determine the water uptake kinetic, the rate of water saturation and the radionuclide source term of irradiated graphite.

Natural graphite is a crystalline allotrope of carbon, made up exclusively of sp2 hybridised carbons. The graphite crystal belongs to the hexagonal system and consists in a compact stacking (AB stacks) of polycyclic aromatic layers (graphene layers). sp2 graphitic materials are most of the time considered as an hydrophobic materiel [4].

Nuclear graphite used in UNGG or other graphite-moderated reactors (GCR) is a synthetic material very far from the crystalline structure of the natural graphite. For UNGG reactors, it was manufactured from petroleum coke mixed with coal-based binder pitch heated and extruded into bricks that were heat-treated up to about $2800 / 3000{ }^{\circ} \mathrm{C}$ for graphitization. During this step, cleaning agents such as $\mathrm{NaF}$ or $\mathrm{MgF}_{2}$ were used to obtain high-purity nuclear graphite grade [5-6-7]. As a result of the mixing of several carbon compounds, this material is structurally heterogeneous at a local scale (more or less anisotropic and not completely graphitized, with internal porosity....). Local heterogeneities in density may be caused either by blowholes or lack of impregnation of the open porosity during the manufacture of the graphite (local drop in density), or by the opposite by the presence of areas very poor in porosity, e.g. due to dense agglomerations of coke grains. Nuclear graphite is more a "carbon-carbon composites" relatively highly graphitised (blend of petroleum coke grains and less highly graphitisable coal-tar pitch) than a monocrystalline natural graphite. The graphite blocks made with this material display good mechanical properties and chemical inertness. Some impurities remain at trace level in the nuclear graphite. Nuclear graphite contains small amounts of impurities like oxygen, hydrogen, metals and halogens, among them chlorine. 


\section{Journal of Nuclear Materials}

86

Irradiation of nuclear graphite but also temperature or radiochemical corrosion during reactor operating, have a major impact on the microstructure of the material at micrometric and nanometric scales [7-8 -9 -10]

- The neutron flux induces displacement cascades of carbon atoms in the graphite matrix leading to structural defects in the material. Indeed, if the neutrons energy is sufficient $(E>0,1 \mathrm{MeV})$, the carbon atoms are ejected out of their initial position and can be for instance displaced between graphite planes, leading to creation of defects in the structure (interstitials, gaps). In the case of irradiation at low temperature, the consequences of the occurrence of these defects are the accumulation of stored energy (call Wigner energy).

- Irradiation temperature is also known to affect the grahite structure during irradiation. A temperature between $200^{\circ} \mathrm{C}$ up to $500^{\circ} \mathrm{C}$ has been found to "heal" some defects, especially the small ones [11 12]. Defects can migrate and interstitial atoms could locally form new carbon layers.

- $\mathrm{CO}_{2}$ radiolysis, mainly initiated through gamma irradiation, induces radiolytic corrosion processes at the gas/graphite interfaces with as consequence a growth of the pore size $[6-7-13]$ and a decrease of the density.

$$
\begin{aligned}
& \mathrm{CO}_{2(\mathrm{~g})}+\mathrm{h} v \rightarrow \mathrm{CO}(\mathrm{g})+\mathrm{O} *(\mathrm{~g}) \\
& \mathrm{O}^{*}+\mathrm{C}(\mathrm{s}) \rightarrow \mathrm{CO}(\mathrm{g})
\end{aligned}
$$

Which taken together is equivalent to the Boudouard reaction:

$$
\mathrm{CO}_{2(\mathrm{~g})}+\mathrm{C}(\mathrm{s}) \rightarrow 2 \mathrm{CO}(\mathrm{g}) \quad \Delta \mathrm{H}=+172 \mathrm{~kJ} \mathrm{~mol}^{-1}
$$

- To avoid or limit the radiolytic corrosion, corrosion inhibitors, such as methane, have been introduced into the coolant during operations, but their radiolytic decomposition leads to the build-up of undesired carbonaceous deposits. Recent analysis of irradiated graphite from two Magnox reactor cores highlighted the presence of a carbonaceous deposit on the exposed surfaces of the graphite bircks [14].

On a chemical point of view the modification of the $\mathrm{C}$ bonding induced by irradiation, radiolytic corrosion or by corrosion inhibitors on the surface lead to the creation of functional group [15 - 16 - 17 - 18]. More precisely, series of carbon-oxygen functional groups have been identified on the surface of irradiated graphite [16 - 18 - 19].

As a consequence the structure (porosity, microstructure and nanostructure) and the surface properties (presence of functional group) of the irradiated graphite are modified and the kinetic of water impregnation must be determined experimentally. That requires also an accurate knowledge of the irradiated graphite property. To assure a phenomena interpretation of water uptake the resulting porosity of the sample must be also determined. It must therefore be emphasized that the graphites used in the context of the UNGG reactor type are materials 


\section{Journal of Nuclear Materials}

that must be more regarded as "carbon composite" (coke + binder) than as homogeneous materials.

The i-graphite of two different reactors - G2 and SLA2 - were investigated for this study. These reactors were chosen due to the different characteristics of their graphite stack and their operating conditions, particularly the type of coke used for the graphite manufacturing, the neutron and thermal power levels, the $\mathrm{CO}_{2}$ pressure and the thermal history of the graphite during reactor operation). Irradiated and unirradiated samples from both reactors were available for comparative studies.

\section{Material and methods}

\section{Graphite samples}

\section{Graphite from the French UNGG G2 reactor}

G2 was the first gas-cooled graphite-moderated reactor designed to produce both electricity and plutonium. It was operated by the CEA from 1958 until 1980 at Marcoule in the south of France [20-21-22]. The graphite used in the G2 reactor was manufactured by Pechiney SA in France. Purified and impregnated, this special coke graphite was used to build the active core of G2. This graphite can be considered as similar to "grade A" graphite previously used in the UK Magnox reactors. During operation, the graphite temperature ranged from $140^{\circ} \mathrm{C}$ to $380^{\circ} \mathrm{C}$.

Within the framework of this study, the irradiated samples chosen were cored in the middle of the pile, as shown in Figure 1. Three of them were taken from the moderating part of the core (numbers 27, 32 \& 42 in Figure 1). Unirradiated samples were also studied. The main characteristics of the irradiated samples from G2 are shown in Table $\mathbf{1}$.

TABLE 1: IRRADIATED SAMPLES FROM THE G2 MODERATOR

\begin{tabular}{|l|c|c|c|c|c|}
\hline $\begin{array}{c}\text { Sample } \\
\text { No. }\end{array}$ & $\begin{array}{c}\text { Sampling } \\
\text { height in the } \\
\text { reactor }(\mathrm{m})\end{array}$ & $\begin{array}{c}\text { Thermal } \\
\text { history }\left({ }^{\circ} \mathrm{C}\right)\end{array}$ & $\begin{array}{c}\text { Fast fluence } \\
\mathrm{E}>0.1 \mathrm{MeV} \\
\left(\mathrm{n} . \mathrm{cm}^{-2}\right)\end{array}$ & $\begin{array}{c}\text { Initial } \\
\text { mass } \\
(\mathrm{g})\end{array}$ & $\begin{array}{c}\text { Dimensions } \\
(\mathrm{mm})\end{array}$ \\
\hline $\mathrm{G} 2-27$ & $13.60-13.80$ & 327 & $4.7 .10^{21}$ & 942 & $\mathrm{H}=160 \varnothing=63$ \\
\hline $\mathrm{G} 2-32$ & $14.60-14.80$ & 320 & $4.7 .10^{21}$ & 863 & $\mathrm{H}=150 \varnothing=63$ \\
\hline $\mathrm{G} 2-42$ & $16.60-16.80$ & 309 & $4.0 .10^{21}$ & 845 & $\mathrm{H}=150 \varnothing=63$ \\
\hline
\end{tabular}




\section{Journal of Nuclear Materials}

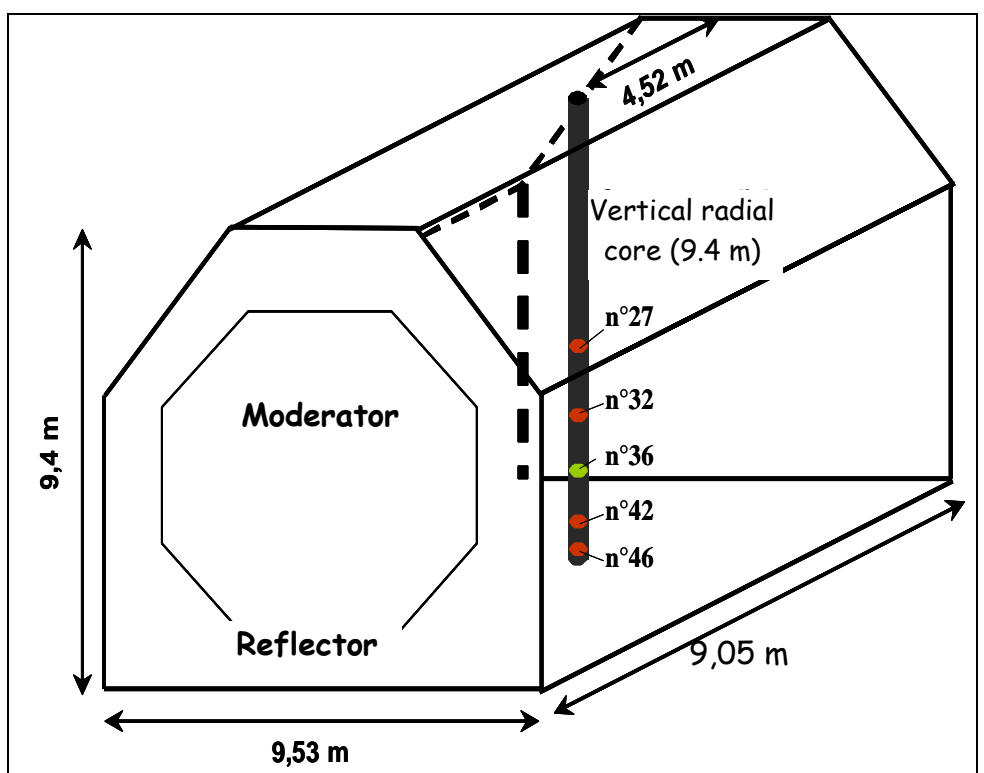

FIGURE 1: G2 REACTOR WITH VERTICAL CORING AND LOCATION OF CORE SAMPLES

- Graphite from the French UNGG St Laurent (SLA2) reactor

The Saint-Laurent A2 (SLA2) reactor was commissioned in August 1971 and shut down in 1992. Its thermal power was $1700 \mathrm{MW}$. The gross electrical power was $530 \mathrm{MWe}$ [23]. The graphite stack of the SLA2 reactor was cylindrical in shape with a vertical axis, a diameter of 15.73 metres and a height of 10.2 metres. The total mass of graphite was 2,440 tonnes. The graphite in the SLA2 stack (moderator or reflector) was made from LIMA coke, which underwent one impregnation and was purified using $\mathrm{MgF}_{2}$. All the graphite was manufactured by the Pechiney/SERS between May 1966 and November 1967. The operating temperature ranged between $240^{\circ} \mathrm{C}$ (top) and $470^{\circ} \mathrm{C}$ (bottom).

This study used twelve samples from two different fuel channels (F10M16-C20 and F7M15C19) located at a radius of $5 \mathrm{~m}$ and $2.95 \mathrm{~m}$ respectively from the reactor centre with variable sampling heights (see Table 2 and Figure 2). Three samples per channel were chosen for structural characterisations and three for water impregnation tests. 


\section{Journal of Nuclear Materials}

TABLE 2: IRRADIATED SAMPLES FROM THE SLA2 MODERATOR

\begin{tabular}{|c|c|c|c|c|c|c|}
\hline $\begin{array}{c}\text { Sample } \\
\text { No. }\end{array}$ & Channel & $\begin{array}{c}\text { Sampling } \\
\text { height in the } \\
\text { reactor }(\mathrm{mm})\end{array}$ & $\begin{array}{c}\text { Thermal } \\
\text { history }\left({ }^{\circ} \mathrm{C}\right)\end{array}$ & $\begin{array}{l}\text { Fast fluence } \\
\mathrm{E}>0.1 \mathrm{MeV} \\
\quad\left(\mathrm{n} . \mathrm{cm}^{-2}\right)\end{array}$ & $\begin{array}{l}\text { Initial } \\
\text { mass } \\
(\mathrm{g})\end{array}$ & $\begin{array}{c}\text { Approximate } \\
\text { dimensions } \\
(\mathrm{mm})\end{array}$ \\
\hline SLA2-43 & F10M16-C20 & 1680 & 430 & $\sim 2.0 .10^{21}$ & 23 & $\mathrm{H}=50 \emptyset=19$ \\
\hline SLA2-44 & F10M16-C20 & 2070 & 435 & $\sim 2.3 .10^{21}$ & 23 & $\mathrm{H}=50 \emptyset=19$ \\
\hline SLA2-53 & F10M16-C20 & 6500 & 330 & $\sim 3.0 .10^{21}$ & 20 & $\mathrm{H}=50 \varnothing=19$ \\
\hline SLA2-55 & F10M16-C20 & 7280 & 310 & $\sim 2.8 .10^{21}$ & 19 & $\mathrm{H}=50 \varnothing=19$ \\
\hline SLA2-58 & F10M16-C20 & 8660 & 270 & $\sim 1.9 .10^{21}$ & 23 & $\mathrm{H}=50 \varnothing=19$ \\
\hline SLA2-60 & F10M16-C20 & 9260 & 250 & $\sim 1.4 .10^{21}$ & 24 & $\mathrm{H}=50 \varnothing=19$ \\
\hline SLA2-122 & F7M15 - C19 & 1080 & 440 & $\sim 1.5 .10^{21}$ & 25 & $\mathrm{H}=50 \varnothing=19$ \\
\hline SLA2-124 & F7M15 - C19 & 2070 & 455 & $\sim 2.3 .10^{21}$ & 25 & $\mathrm{H}=50 \varnothing=19$ \\
\hline SLA2-129 & F7M15 - C19 & 4480 & 400 & $\sim 3.3 .10^{21}$ & 24 & $\mathrm{H}=50 \varnothing=19$ \\
\hline SLA2-135 & F7M15 - C19 & 7280 & 310 & $\sim 2.8 .10^{21}$ & 22 & $\mathrm{H}=50 \varnothing=19$ \\
\hline SLA2-138 & F7M15 - C19 & 8660 & 270 & $\sim 1.9 .10^{21}$ & 24 & $\mathrm{H}=50 \varnothing=19$ \\
\hline SLA2-139 & F7M15 - C19 & 9260 & 250 & $\sim 1.4 .10^{21}$ & 24 & $\mathrm{H}=50 \varnothing=19$ \\
\hline
\end{tabular}

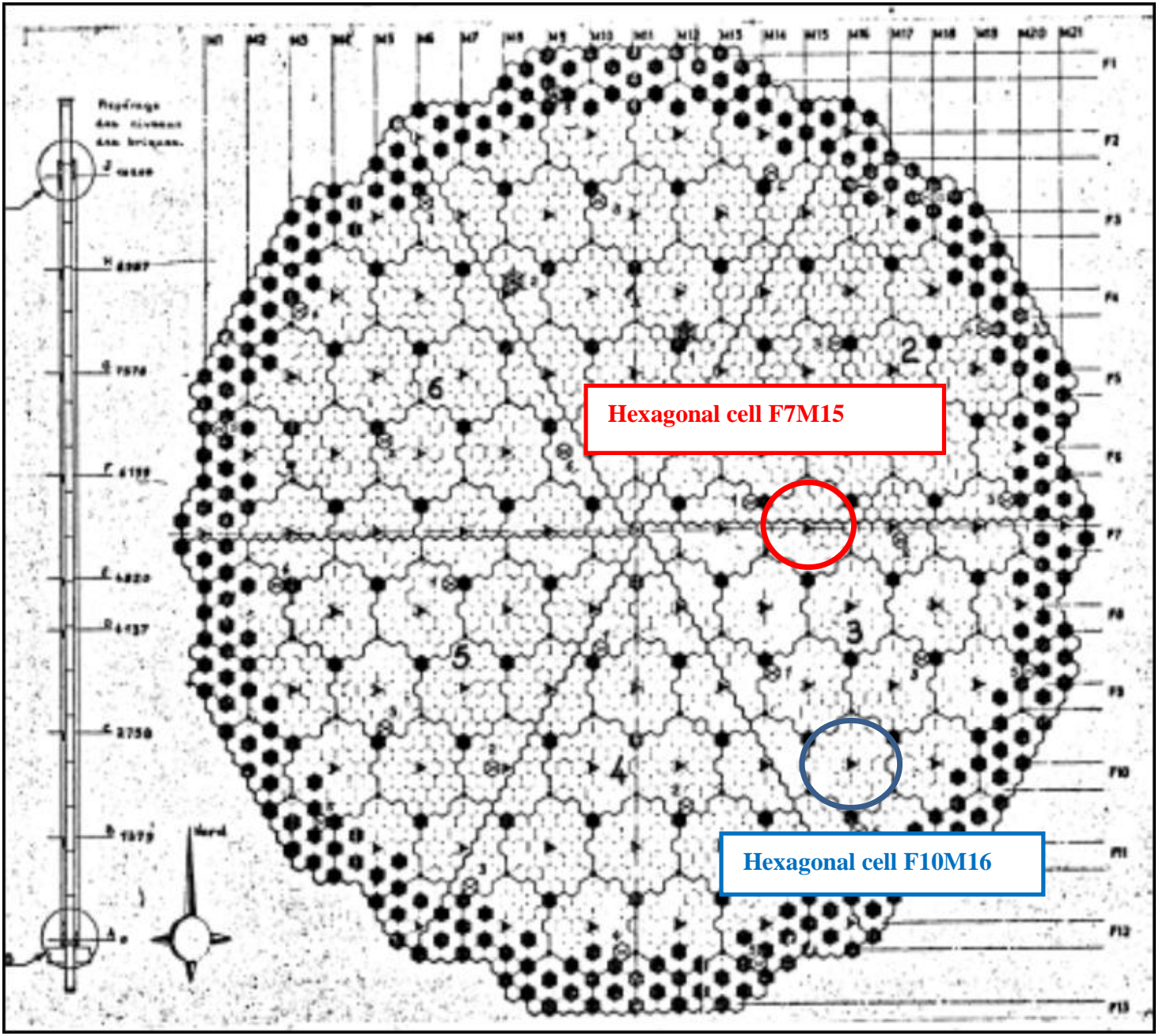

FIGURE 2: SECTION THROUGH THE GRAPHITE STACK OF THE SAINT-LAURENT A2 


\section{Journal of Nuclear Materials}

177

178

179

180

181

182

183

\begin{tabular}{|c|c|c|}
\hline \multicolumn{3}{|c|}{ IRRADIATION $)$} \\
\hline Reactor & $\begin{array}{c}\text { G2 } \\
\text { Moderator } \\
\text { Special A grade } \\
\text { coke } \\
\text { NaF cleaned }\end{array}$ & $\begin{array}{c}\text { SIMA coke } \\
\text { MgF } 2 \text { cleaned }\end{array}$ \\
\hline Graphite density & $\sim 1.71$ & $\sim 1.68$ \\
\hline Capture section $($ mbarn $)$ & 3.95 & 3.75 \\
\hline $\begin{array}{c}\text { Thermal expansion coefficient } \\
\left(25-525^{\circ} \mathrm{C}\right) \alpha(/ /)\end{array}$ & $1.25 .10^{-6} \mathrm{~K}^{-1}$ & $2.4 .10^{-6} \mathrm{~K}^{-1}$ \\
\hline Anisotropy ratio $\alpha(\perp) / \alpha(/ /))$ & 2.3 & 1.6 \\
\hline Compression $(/ /)$ & $27 \mathrm{MPa}^{-1}$ & $42 \mathrm{MPA}$ \\
\hline Ash content $(\mathrm{ppm})$ & $106 \mathrm{to} 125$ & 98 \\
\hline
\end{tabular}

TABLE 3: OPERATING CONDITIONS OF THE G2 AND SLA2 REACTORS

\begin{tabular}{|c|c|c|}
\hline Reactor & G2 & SLA2 \\
\hline First criticality & July 1958 & June 1971 \\
\hline Shutdown & February 1980 & May 1992 \\
\hline Thermal power $(\mathrm{MW})$ & 260 & 1700 \\
\hline $\mathrm{CO}_{2}$ pressure $(\mathrm{MPa})$ & 1.5 & 28.5 \\
\hline $\begin{array}{c}\text { Mass of graphite stack } \\
\text { (tonnes) }\end{array}$ & 1,500 & 2,200 \\
\hline $\begin{array}{c}\text { Graphite temperature during } \\
\text { operation }\end{array}$ & $140-380^{\circ} \mathrm{C}$ & $240-470^{\circ} \mathrm{C}$ \\
\hline
\end{tabular}

TABLE 4: CHARACTERISTICS OF THE G2 AND SLA2 REACTOR GRAPHITE (BEFORE IRRADIATION)

The main characteristics of the G2/SLA2 reactor and graphite are given in Table 3 and Table 4

184 


\section{Journal of Nuclear Materials}

186

198

\begin{tabular}{|c|c|c|c|c|c|c|c|}
\hline \multirow[b]{2}{*}{ Graphite } & \multicolumn{3}{|c|}{ Reference } & \multirow{2}{*}{$\begin{array}{c}\text { Mass } \\
(\mathrm{g})\end{array}$} & \multirow{2}{*}{$\begin{array}{c}\text { Average } \\
\text { dimensions } \\
\\
(\mathrm{cm})\end{array}$} & \multirow{2}{*}{$\begin{array}{c}\text { Surface } \\
\mathrm{cm}^{2}\end{array}$} & \multirow{2}{*}{$\begin{array}{c}\text { Volume } \\
\mathrm{cm}^{3}\end{array}$} \\
\hline & sample & Form & $\begin{array}{c}\text { Water } \\
\text { uptake } \\
\text { test }\end{array}$ & & & & \\
\hline \multirow{7}{*}{$\begin{array}{l}\text { Unirradiated } \\
\text { graphite }\end{array}$} & $5-1$ & cube & $\mathrm{A}$ & 7.2085 & $1.5 * 1.5 * 2.0$ & $16.3 \pm 0.4$ & $4.41 \pm 0.13$ \\
\hline & $5-2$ & cube & A & 3.6199 & $1.5 * 1.4 * 1$ & $10.5 \pm 0.2$ & $2.25 \pm 0.06$ \\
\hline & $5-3$ & cube & B & 10.477 & $1.5 * 1.4 * 2.9$ & $21.5 \pm 0,8$ & $6.33 \pm 0.21$ \\
\hline & $5-8$ & cube & $\mathrm{B}$ & 10.9432 & $1.5 * 1.5 * 2.9$ & $22.0 \pm 0.3$ & $6.59 \pm 0.13$ \\
\hline & $5-9$ & cube & $\mathrm{B}$ & 11.9068 & $3 * 2.9 * 0.85$ & $27.2 \pm 0.5$ & $7.30 \pm 0.22$ \\
\hline & $5-10$ & cube & A & 15.526 & $3.01 * 1.07 * 2.88$ & $29.8 \pm 0.4$ & $9.22 \pm 0.22$ \\
\hline & 5-11 & cube & $\mathrm{A}$ & 10.7028 & $1.5 * 1.4 * 2.9$ & $21.5 \pm 0.8$ & $6.39 \pm 0.25$ \\
\hline \multirow{6}{*}{$\begin{array}{l}\text { Irradiated } \\
\text { graphite }\end{array}$} & \multirow{2}{*}{ G2-27 } & Cube & A & 12.1629 & $1.53 * 1.53 * 3.02$ & $23.2 \pm 0.4$ & $7.07 \pm 0.10$ \\
\hline & & Cylinder & B & 80.0304 & $6.32 * 1.53$ & $93.1 \pm 1.3$ & $48.0 \pm 0.7$ \\
\hline & \multirow{2}{*}{$\mathrm{G} 2-32$} & Cube & $\mathrm{A}$ & 10.5228 & $1.47 * 1.46 * 3.12$ & $22.5 \pm 0.6$ & $6.66 \pm 0.14$ \\
\hline & & Cylinder & B & 72.0947 & $6.32 * 1.40$ & $90.5 \pm 1.4$ & $43.9 \pm 0.7$ \\
\hline & \multirow{2}{*}{ G2-42 } & Cube & $\mathrm{A}$ & 13.2756 & $1.61 * 1.52 * 3.12$ & $24.4 \pm 0.4$ & $7.64 \pm 0.11$ \\
\hline & & Cylinder & $\mathrm{B}$ & 82.044 & $6.32 * 1.50$ & $92.5 \pm 1.3$ & $47.1 \pm 0.7$ \\
\hline
\end{tabular}

\section{Origin and preparation of samples}

\author{
Graphite from the French $U N G G$ G2 reactor
}

Each sample was considered as homogeneous from a neutronic and thermal point of view. Successive slices of about 1 to $3 \mathrm{~cm}$ were cut using a wire saw in a glove box (Figure 3). Some slices were re-cut to obtain smaller samples for porosity measurements. The dimensions of unirradiated and irradiated samples used for the water uptake tests are given in Table 5. Other samples were used for porosity measurements.

TABLE 5: GEOMETRICAL CHARACTERISTICS OF THE SAMPLES FROM G2 FOR WATER UPTAKE TESTS 


\section{Journal of Nuclear Materials}

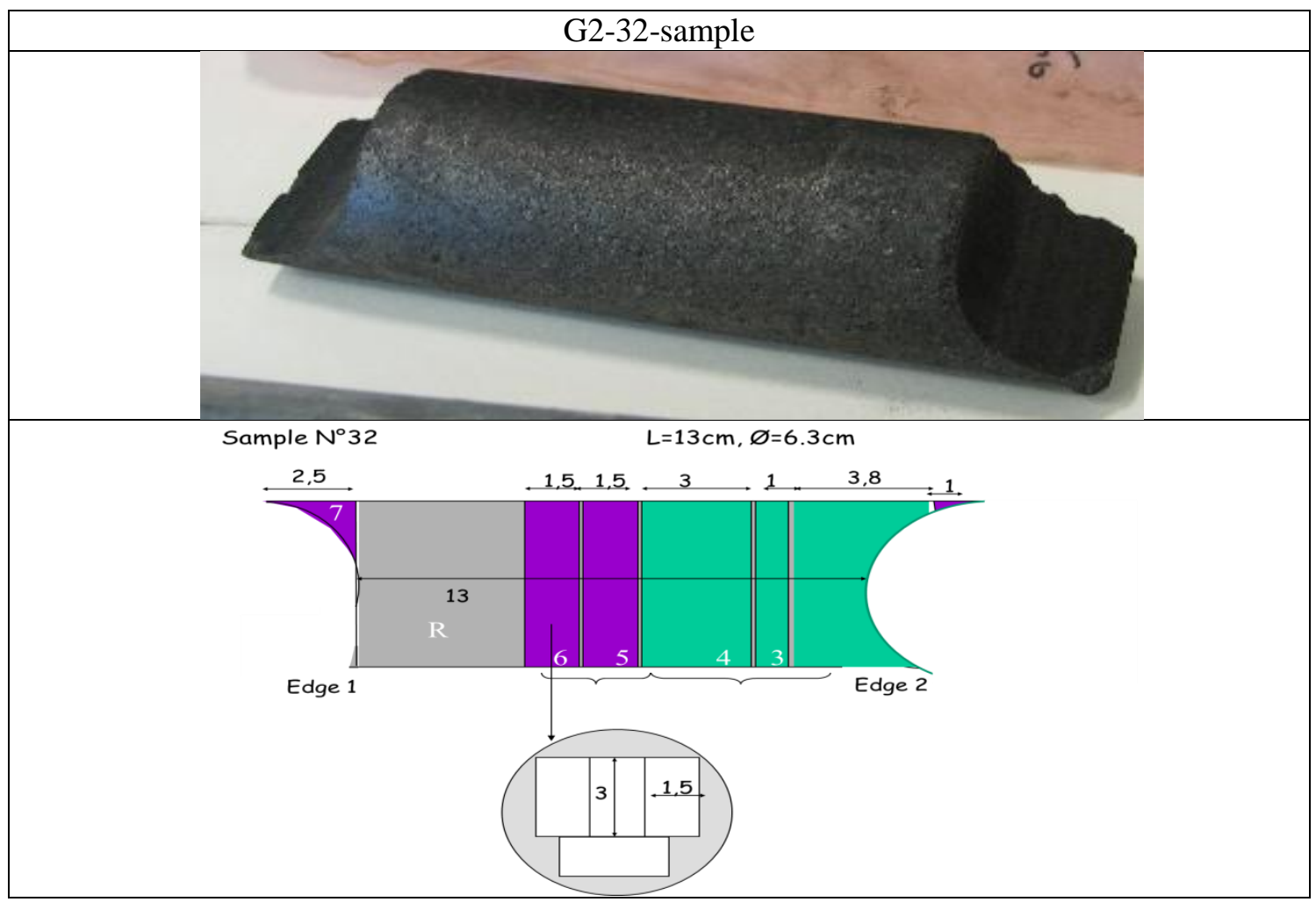

FIGURE 3: CUTS MADE ON THE CORE OF THE G2 GRAPHITE MODERATOR 


\section{Journal of Nuclear Materials}

\section{- Graphite from the French UNGG SLA2 reactor}

Initially irradiated samples were in the form of cylindrical cores (approximate dimensions: diameter $19 \mathrm{~mm}$ / height $50 \mathrm{~mm}$ ) with a bevelled end corresponding to the outer surface of the brick (Figure 4). In order to perform density and water uptake measurements, it was necessary to re-machine the samples. For density measurements, samples were cut into semi-circles of about $10 \mathrm{~mm}$ thick. For the six samples chosen for the impregnation tests, these semi-circles were used to measure porosity (helium pycnometry and mercury porosimetry). The rest of the core, i.e. about $40 \mathrm{~mm}$ long, was kept for continuous water impregnation tests. Figure 4 shows how the samples were divided up for the different characterisations.

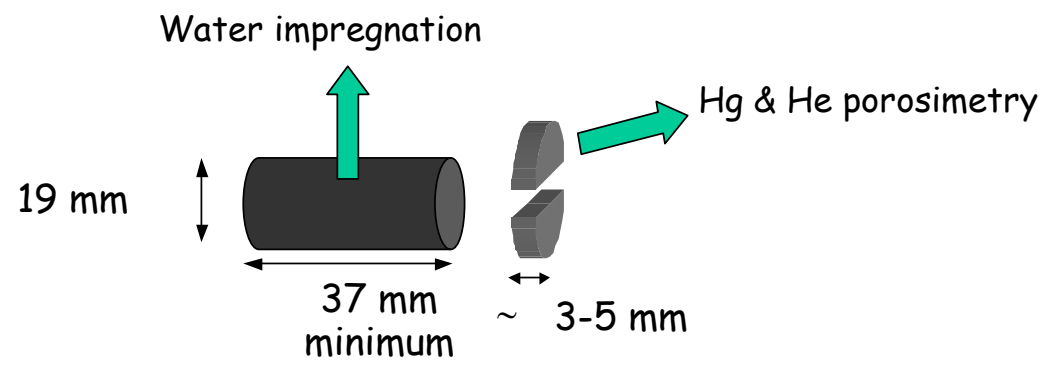

FIGURE 4: SLA2 GRAPHITE SAMPLES AND THEIR DISTRIBUTION FOR THE DIFFERENT ANALYSES

The dimensions of the entire sample used for water impregnation tests after cutting are indicated in Table 6.

\begin{tabular}{|c|c|c|c|c|c|c|c|}
\hline \multirow[b]{2}{*}{ Graphite } & \multicolumn{3}{|c|}{ Reference } & \multirow{2}{*}{$\begin{array}{c}\text { Mass } \\
(\mathrm{g})\end{array}$} & \multirow{2}{*}{$\begin{array}{c}\begin{array}{c}\text { Average } \\
\text { dimensions }\end{array} \\
\begin{array}{c}\text { Diam.*L. } \\
(\mathrm{mm} * \mathrm{~mm})\end{array}\end{array}$} & \multirow{2}{*}{$\begin{array}{c}\text { Surface } \\
\mathrm{cm}^{2}\end{array}$} & \multirow{2}{*}{$\begin{array}{c}\text { Volume } \\
\mathrm{cm}^{3}\end{array}$} \\
\hline & sample & form & $\begin{array}{c}\text { Water } \\
\text { uptake } \\
\text { test }\end{array}$ & & & & \\
\hline \multirow{3}{*}{$\begin{array}{l}\text { Unirradiated } \\
\text { graphite }\end{array}$} & $\mathrm{Z} 1$ & cylinder & $\mathrm{A}$ & 4.0085 & $12 * 21$ & $10.1 \pm 0.3$ & $2.35 \pm 0.03$ \\
\hline & $\mathrm{Z} 2$ & cylinder & A & 7.7454 & $12 * 41$ & $17.7 \pm 0.4$ & $4.63 \pm 0.02$ \\
\hline & XY1 & cylinder & $\mathrm{A}$ & 7.5475 & $12 * 39$ & $17.1 \pm 0.4$ & $4.44 \pm 0.02$ \\
\hline \multirow{6}{*}{$\begin{array}{l}\text { Irradiated } \\
\text { graphite }\end{array}$} & SLA2-44 & cylinder & $\mathrm{A}$ & 21.9988 & $19 * 48$ & $34 \pm 1$ & $13.6 \pm 0.4$ \\
\hline & SLA2-55 & cylinder & A & 17.9422 & $19 * 39$ & $29 \pm 1$ & $11.1 \pm 0.3$ \\
\hline & SLA2-58 & cylinder & A & 22.1746 & $19 * 47$ & $33.5 \pm 0.9$ & $13.2 \pm 0.3$ \\
\hline & SLA2-124 & cylinder & $\mathrm{A}$ & 22.0483 & $19 * 50$ & $35.7 \pm 1.1$ & $14.2 \pm 0.4$ \\
\hline & SLA2-135 & cylinder & A & 23.1589 & $19 * 51$ & $36.1 \pm 1.9$ & $14.5 \pm 0.8$ \\
\hline & SLA2-138 & cylinder & $\mathrm{A}$ & 22.0355 & $19 * 50$ & $35.4 \pm 2.7$ & $14.1 \pm 1.1$ \\
\hline
\end{tabular}




\title{
Journal of Nuclear Materials
}

\section{Materials and methods}

\author{
Water uptake methodology
}

The study involved monitoring the change in the mass of samples immersed in water over time. Two techniques were used: continuous measurements for immersed samples suspended from a precision electronic balance (Test A), and intermittent measurements of the mass variations in immersed samples placed in experimental vessels (Test B).

In the first case, the sample was hung from a Sartorius balance beam and fully immersed in a container filled with ultrapure water. This configuration made it possible to continuously measure any changes in the apparent mass of the samples in water. As the water impregnates the sample, the buoyant force decreases and the apparent mass increases, which therefore makes it possible to determine the water mass having impregnated the sample. Measurements were taken over periods of about 10 to 40 days depending on the sample.

In order to determine the long-term impregnation kinetics, the samples were placed in reaction vessels filled with ultrapure water while making sure the $S / V$ remained the same. The sample masses were measured regularly as follows: the sample was removed from the reaction vessel, gently wiped with paper towelling to remove the surface layer of water, weighed, and then put back in the reaction vessel.

\section{Density measurements}

Geometric densities were obtained by measuring the dimensions of the samples with a sliding calliper (uncertainty of $0.1 \mathrm{~mm}$ ) by recording several readings per level, and weighing samples on a precision balance. The propagation of uncertainties, notably on average values, was calculated in accordance with standard engineering techniques.

\section{Helium pycnometry}

The non-destructive technique known as pycnometry by helium displacement is used to measure the internal volume of a porous material and to deduce its density from its mass. The measurement principle relies on the properties of helium, which behaves like an ideal gas. It is first pressurised within a reference chamber of a known volume before opening the pressurised chamber (sample) of a known volume. Pressure changes are associated with the porosity of the sample. Gas fills up the open porosities of the sample, while only the dense fraction and the sealed porosities of the sample remain inaccessible. The cells being used allow measurements on samples ranging from 1 to $10 \mathrm{~g}$. 


\section{Journal of Nuclear Materials}

\section{Mercury porosimetry}

The destructive technique known as porosimetry by mercury intrusion is designed to determine the distribution of the pore sizes within a porous material (solid or powder). The measurement principle relies on the properties of a non-wetting liquid at ambient temperature, such as mercury. Mercury needs to be forced to penetrate the pores of a porous material. Any intrusion pressure, $P$, which is necessary for mercury to penetrate a pore with a diameter, $d$, is provided by the Laplace relation, as follows:

$$
P=\frac{4 \gamma \cos \theta}{d}
$$

$$
\begin{aligned}
& \text { where } P \text { is the intrusion pressure of mercury }(P a) \\
& \gamma \text { is the surface tension of mercury }(\mathrm{Pa} / \mathrm{m}) \\
& \theta \text { is the wetting angle of mercury on pore surface }\left(^{\circ}\right) \\
& d \text { is the pore diameter (m) }
\end{aligned}
$$

The pressure applied to the mercury is increased by increments and the volumes of mercury penetrating the porous solid are recorded at each increment. The cumulative pore volume is then obtained as a function of the intrusion pressure or the diameter of the pores. The derivative gives the pore distribution of the solid. Knowing the density of the solid, the total quantity of mercury introduced into the solid can be used to determine the total porosity. This method of study has some drawbacks. In particular, the high pressure (about $400 \mathrm{MPa}$ ) applied to the mercury for it to penetrate the finest pores (a few nanometres in diameter) may alter the material studied. For this reason, the main advantage of this technique is its ability to determine the pore size distribution. The use of Laplace's law amounts to considering all the pores as cylinders, which is far removed from reality. Moreover, it must be assumed that the only sensitive factor is the diameter of the pore entrances. But significant hysteresis phenomena may conceal the actual pore structure. However, this technique is very useful for comparing different materials and provides a conventional representation of the pore structure.

During this study, a Micromeritics porosimeter (Model 9420 in a glove box,) was used to record measurements in a radioactive environment on inactive or irradiated samples. 


\title{
Journal of Nuclear Materials
}

\section{Results and discussion}

\author{
Part 1 - Density and porosity
}

\section{Density}

The results are shown in Table 7 for the G2 samples and in the Table 8 for the SLA2 samples. As mentioned earlier, the G2 graphite cores were recut to obtain specific samples for water impregnation tests and specific samples were used for porosity measurements. The geometric density readings from prismatic and cylindrical lamellae proved to be consistent for all the irradiated samples (Table 7).

In case of the SLA samples, only one semi-circular disc was used for helium and mercury porosity measurements. Due to the lack of irradiated samples and the relatively small dimensions, it was not possible to perform reproducibility studies for the density and porosity measurements.

TABLE 7: DENSITY AND POROSITY OF THE SAMPLES FROM G2

\begin{tabular}{|c|c|c|c|c|c|}
\hline & $\begin{array}{c}\text { Average } \\
\text { density }\left(\boldsymbol{\rho}_{G}\right)\end{array}$ & $\begin{array}{c}\boldsymbol{\rho}_{\mathrm{S}} \\
\text { Helium }\end{array}$ & $\begin{array}{c}\text { Total porosity } \\
\text { Ref } \boldsymbol{d}=2.266\end{array}$ & $\begin{array}{c}\text { Open } \\
\text { porosity } \\
\left(1-\rho_{G} / \boldsymbol{\rho}_{\mathrm{S}}\right)\end{array}$ & $\begin{array}{c}\text { Sealed } \\
\text { porosity }\end{array}$ \\
\hline $\begin{array}{c}\text { UNIRRADIATED } \\
\text { Coke special } \\
\text { (average n=8) }\end{array}$ & $1.69 \pm 0.06$ & $2.15 \pm 0.05$ & $25.9 \pm 0.9$ & $21.7 \pm 1.2$ & $4.9 \pm 1.4$ \\
\hline G2-27-1 & $1.67 \pm 0.05$ & $2.17 \pm 0.09$ & $26.3 \pm 0.6$ & $22.9 \pm 1.1$ & $3.4 \pm 1.2$ \\
\hline G2-27-3 & $1.62 \pm 0.04$ & $2.18 \pm 0.05$ & $28.5 \pm 0.4$ & $25.7 \pm 1.3$ & $2.8 \pm 0.8$ \\
\hline G2-27-7 & $1.65 \pm 0.05$ & $2.27 \pm 0.09$ & $27.2 \pm 0.7$ & $27.3 \pm 1.3$ & $-0.1 \pm 1.4$ \\
\hline G2-27-8 & $1.68 \pm 0.05$ & $2.22 \pm 0.09$ & $25.9 \pm 0.6$ & $24.3 \pm 1.1$ & $1.7 \pm 1.3$ \\
\hline G2-27 MEAN & $1.66 \pm 0.06$ & $2.21 \pm 0.09$ & $27.0 \pm 0.6$ & $25.0 \pm 1.1$ & $1.9 \pm 1.3$ \\
\hline G2-32-1 & $1.67 \pm 0.05$ & $2.16 \pm 0.09$ & $26.5 \pm 0.7$ & $22.91 \pm 1.1$ & $3.5 \pm 1.3$ \\
\hline G2-32-3 & $1.62 \pm 0.05$ & $2.19 \pm 0.05$ & $28.5 \pm 0.7$ & $26.0 \pm 1.0$ & $2.5 \pm 0.8$ \\
\hline G2-32-6 & $1.65 \pm 0.05$ & $2.18 \pm 0.09$ & $27.1 \pm 0.7$ & $24.3 \pm 1.1$ & $2.8 \pm 1.3$ \\
\hline G2-32-7 & $1.67 \pm 0.05$ & $2.17 \pm 0.09$ & $26.4 \pm 0.7$ & $23.0 \pm 1.1$ & $3.4 \pm 1.3$ \\
\hline G2-32 MEAN & $1.65 \pm 0.05$ & $2.18 \pm 0.09$ & $27.1 \pm 0.7$ & $24.0 \pm .1 .1$ & $3.1 \pm 1.5$ \\
\hline G2-42-1 & $1.71 \pm 0.05$ & $2.11 \pm 0.09$ & $24.5 \pm 0.7$ & $19.1 \pm 0.9$ & $5.4 \pm 1.2$ \\
\hline G2-42-3 & $1.71 \pm 0.05$ & $2.18 \pm 0.09$ & $24.5 \pm 0.6$ & $21.6 \pm 0.9$ & $3.0 \pm 0.6$ \\
\hline G2-42-6 & $1.69 \pm 0.05$ & $2.17 \pm 0.09$ & $24.3 \pm 0.7$ & $20.8 \pm 1.0$ & $4.9 \pm 1.1$ \\
\hline G2-42-7 & $1.70 \pm 0.05$ & $2.14 \pm 0.09$ & $24.8 \pm 0.7$ & $20.5 \pm 1.0$ & $5.8 \pm 1.1$ \\
\hline G2-42 MEAN & $1.70 \pm 0.06$ & $2.15 \pm 0.09$ & $24.5 \pm 0.7$ & $20.5 \pm 1.0$ & $4.8 \pm 1.1$ \\
\hline
\end{tabular}




\section{Journal of Nuclear Materials}

TABLE 8: DENSITY AND POROSITY OF THE SAMPLES FROM SLA2

\begin{tabular}{|c|c|c|c|c|c|}
\hline & $\begin{array}{c}\text { AVERAGE } \\
\text { DENSITY } \\
\left(\boldsymbol{\rho}_{G}\right)\end{array}$ & $\begin{array}{c}\boldsymbol{\rho}_{\mathrm{S}} \\
\text { Helium }\end{array}$ & $\begin{array}{c}\text { Total } \\
\text { porosity } \\
\text { Ref } \boldsymbol{d}=\mathbf{2 . 2 6 6}\end{array}$ & $\begin{array}{c}\text { Open } \\
\text { porosity } \\
\left(1-\boldsymbol{\rho}_{G /} \boldsymbol{\rho}_{\mathrm{S})}\right.\end{array}$ & $\begin{array}{c}\text { Sealed } \\
\text { porosity }\end{array}$ \\
\hline $\begin{array}{c}\text { UNIRRADIATED } \\
(\text { average }=8)\end{array}$ & $1.69 \pm 0.03$ & $2.12 \pm 0.05$ & $25.7 \pm 0.9$ & $20.7 \pm 0.7$ & $5.0 \pm 1.0$ \\
\hline SLA2-43 & $1.58 \pm 0.04$ & $2.11 \pm 0.05$ & $30.2 \pm 0.9$ & $25.1 \pm 1.1$ & $5.2 \pm 1.3$ \\
\hline SLA2-44 & $1.61 \pm 0.05$ & $2.04 \pm 0.05$ & $29.1 \pm 0.9$ & $21.3 \pm 1.2$ & $7.8 \pm 1.3$ \\
\hline SLA2-53 & $1.61 \pm 0.04$ & $2.12 \pm 0.05$ & $28.9 \pm 0.9$ & $24.0 \pm 1.2$ & $4.9 \pm 1.2$ \\
\hline SLA2-55 & $1.62 \pm 0.04$ & $2.13 \pm 0.07$ & $28.6 \pm 0.8$ & $24.2 \pm 1.0$ & $4.4 \pm 1.4$ \\
\hline SLA2-58 & $1.68 \pm 0.04$ & $2.05 \pm 0.15$ & $26.0 \pm 0.7$ & $18.3 \pm 1.4$ & $7.7 \pm 1.6$ \\
\hline SLA2-60 & $1.73 \pm 0.04$ & $2.09 \pm 0.05$ & $23.7 \pm 0.8$ & $17.2 \pm 1.2$ & $6.4 \pm 1.6$ \\
\hline SLA2-122 & $1.67 \pm 0.04$ & $2.12 \pm 0.05$ & $26.3 \pm 0.9$ & $21.2 \pm 1.2$ & $5.1 \pm 1.6$ \\
\hline SLA2-124 & $1.55 \pm 0.05$ & $2.05 \pm 0.15$ & $31.5 \pm 1.1$ & $24.3 \pm 1.9$ & $7.2 \pm 2.1$ \\
\hline SLA2-129 & $1.59 \pm 0.04$ & $2.13 \pm 0.05$ & $29.8 \pm 0.9$ & $25.4 \pm 1.4$ & $4.5 \pm 1.2$ \\
\hline SLA2-135 & $1.60 \pm 0.09$ & $2.02 \pm 0.15$ & $29.2 \pm 1.7$ & $20.8 \pm 1.7$ & $8.5 \pm 1.9$ \\
\hline SLA2-138 & $1.56 \pm 0.12$ & $2.15 \pm 0.18$ & $31.0 \pm 2.4$ & $27.3 \pm 2.4$ & $3.7 \pm 2.6$ \\
\hline SLA2-139 & $1.63 \pm 0.04$ & $2.12 \pm 0.05$ & $28.1 \pm 0.9$ & $23.1 \pm 1.2$ & $4.6 \pm 1.7$ \\
\hline & & & & & \\
\hline
\end{tabular}

It can be seen that the irradiated graphite densities are mostly slightly lower than those of the unirradiated graphite. This decrease in density is associated with an increase in open porosity, and is certainly related to the wear of graphite under irradiation (radiolytic corrosion by the $\mathrm{CO}_{2}$ coolant).

There are some exceptions: sample No. 42 from G2, whose density can be considered as identical as before irradiation, was the first moderator core sample taken at the limit of the reflector. The porosity values are almost identical to those determined for the inactive brick. It was not as irradiated and was exposed to a lower temperature than the two others. This leads us to believe that radiolytic corrosion may be considered as negligible in this area (at the boundary between the reflector and the moderator).

Two SLA2 samples (SLA2-58 and 60) revealed an equivalent or higher density than those determined for unirradiated graphite, together with a very low open porosity. These samples must have come from a batch manufactured with a higher level of impregnation.

In the other case of the G2 or SLA moderator samples, it could be seen that the increase in the total porosity was linked to an increase in the open porosity. More precisely, it appears that the open porosity level generally correlates with the neutron fluence received by the samples, and therefore with the position in the graphite stack. The level of closed porosity remains constant or slightly higher than the reference in the case of SLA2 samples, whereas the sealed porosity decreased in the case of G2. It is more complex to assess the variation in closed porosity according to the position of the samples in the core. In light of these results, the decrease in sample density definitely results from the radiolytic corrosion of the graphite. 


\section{Journal of Nuclear Materials}

\section{Pore size distribution}

The variation in pore volume according to the diameter of the pores and the pore distribution of the samples are shown in Figure 5 for unirradiated samples, in Figure 6 for the G2 sample, and in Figure 7 for SLA2 samplesErreur ! Source du renvoi introuvable..

It can be seen that the pore size distribution for unirradiated samples differs between the two types of graphite. For G2 graphite (special coke graphite), around 75\% of the total porous volume of the sample lies within a pore diameter range between 1 and $30 \mu \mathrm{m}$ with a maximum distribution oscillating towards $3.5 \mu \mathrm{m}$.

In the case of the SLA2 samples manufactured with LIMA coke, it appears that unirradiated graphite has two types of distribution: around 35\% of the pores in the mesoporous domain (pore diameter between 1 and $300 \mathrm{~nm}$ ), and $40 \%$ of the total porosity in the macroporous zone between 1 to $4 \mu \mathrm{m}$ with a peak at around $2.2 \mu \mathrm{m}$. These results are in accordance with some characterisations performed on other types of nuclear graphite [24].

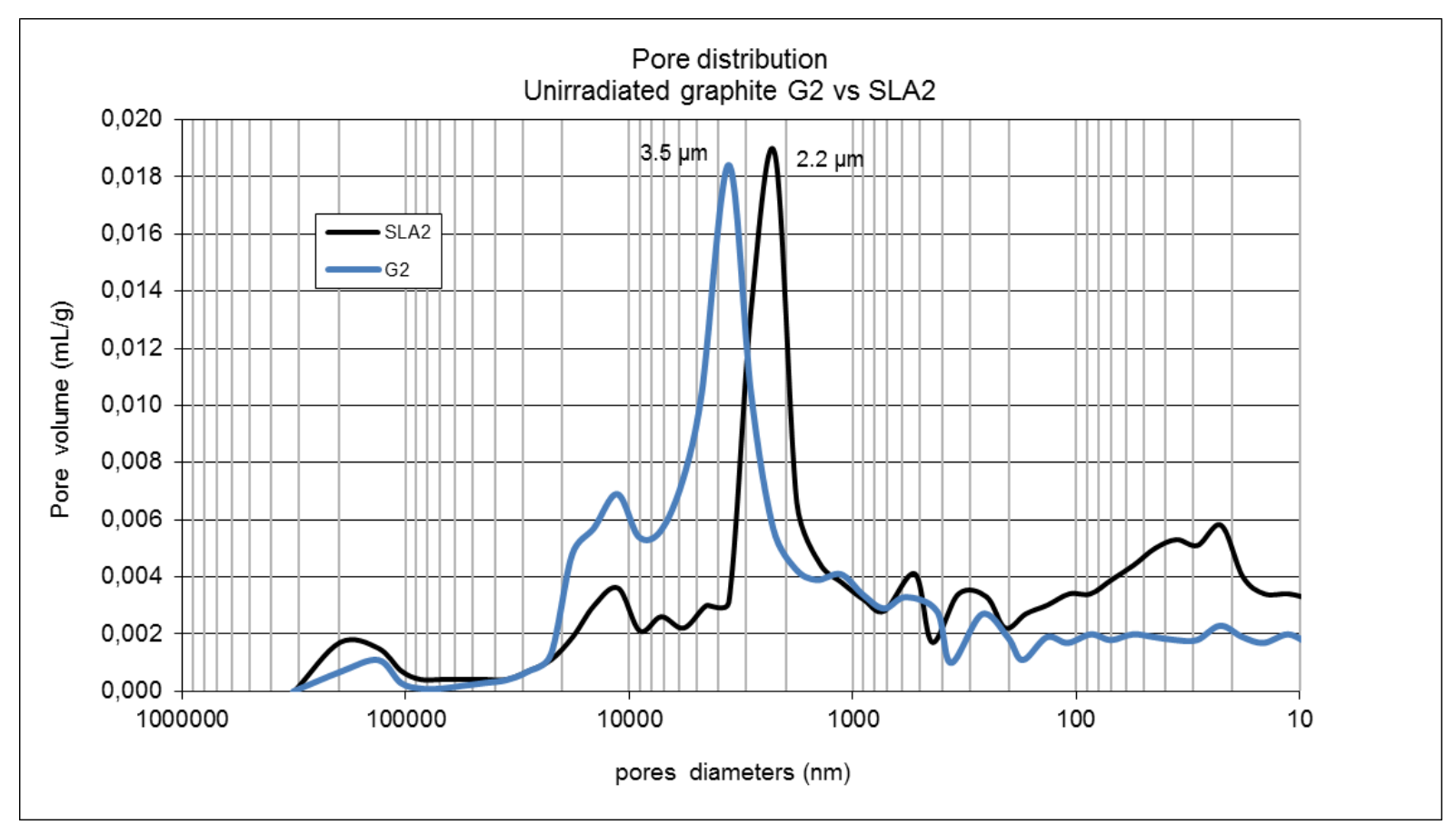

FIGURE 5: COMPARISON OF PORE DISTRIBUTIONS FOR UNIRRADIATED GRAPHITE SAMPLES FROM THE SLA2 REACTOR MODERATOR (LIMA COKE) AND THE G2 REACTOR MODERATOR (SPECIAL COKE) 


\section{Journal of Nuclear Materials}

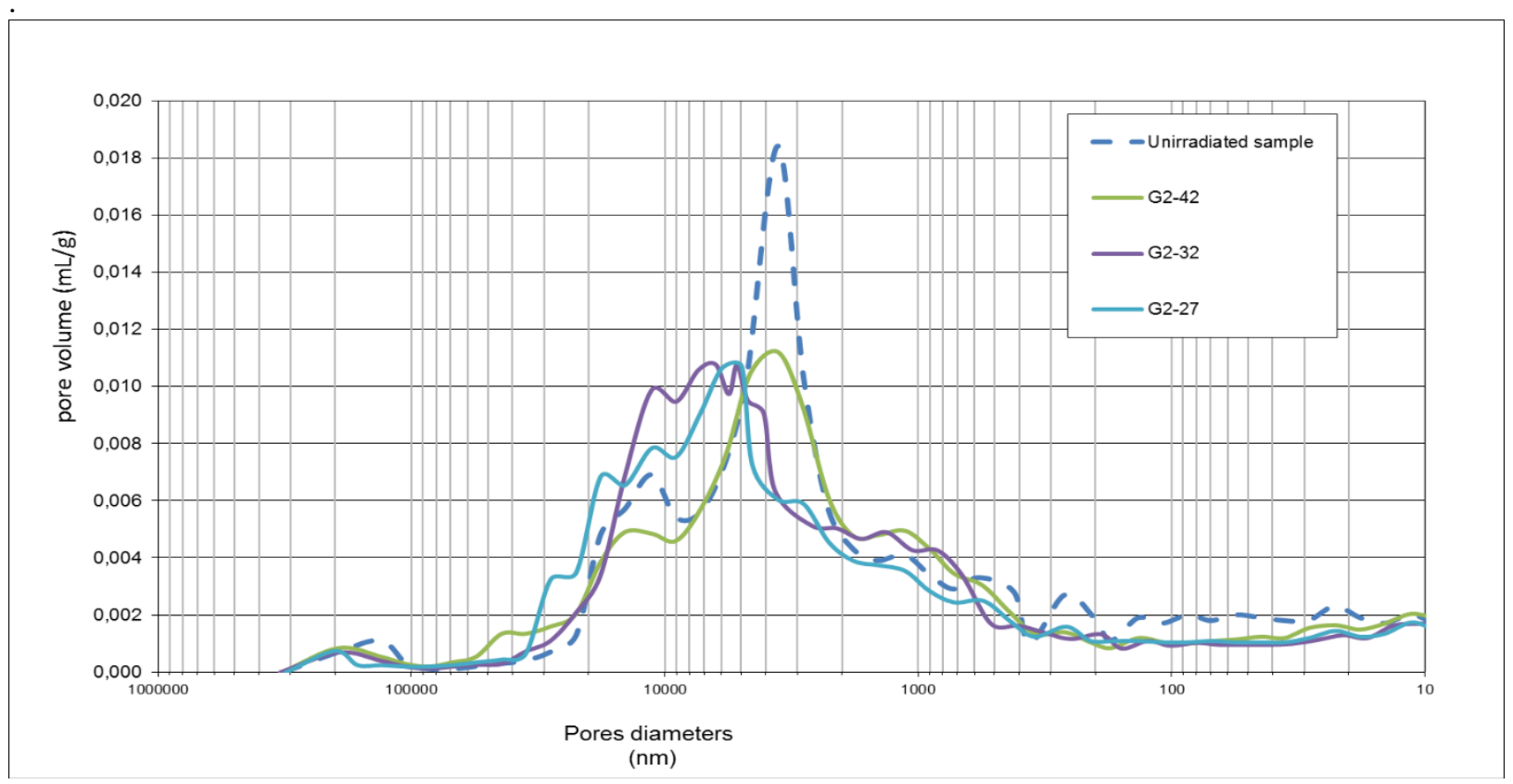

FIGURE 6: PORE DISTRIBUTIONS FOR IRRADIATED AND UNIRRADIATED GRAPHITE SAMPLES FROM THE G2 REACTOR MODERATOR (SPECIAL COKE)

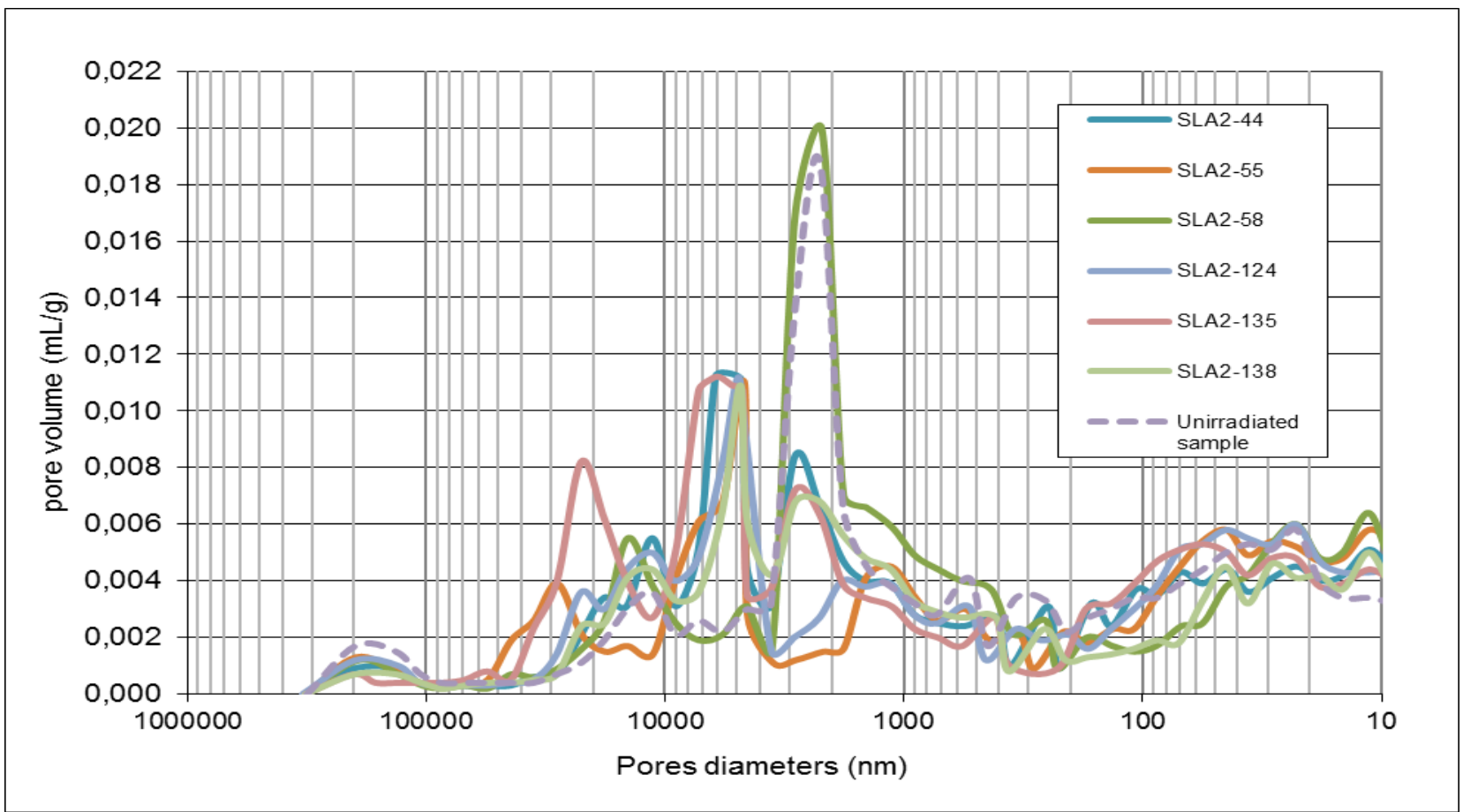

FIGURE 7: PORE DISTRIBUTIONS FOR IRRADIATED AND UNIRRADIATED GRAPHITE $\underline{\text { SAMPLES FROM THE SLA2 REACTOR MODERATOR (LIMA COKE) }}$ 


\section{Journal of Nuclear Materials}

368 A general increase in the macroporosity could be seen in the G2 graphite after irradiation 369 (pore diameters ranging between 1 and $30 \mu \mathrm{m}$ ), including a wider pore size distribution 370 mostly for the G2-27 (68\% porosity) and G2-32 (72\% porosity) samples with a modification 371 in the average pore radius in the distribution. The average radius increased from $3.5 \mu \mathrm{m}$ on 372 inactive samples to $4.3 \mu \mathrm{m}$ for sample G2-42, then to $5.4 \mu \mathrm{m}$ for sample G2-32, before 373 reaching $5.7 \mu \mathrm{m}$ for sample G2-27.

374 Overall, it appears that the fraction of pores in the mesoporosity domain (pore diameter 375 between 1 and $300 \mathrm{~nm}$ ) is not affected in the case of SLA2 irradiated samples. The intensity 376 of the peak in porosity at about $1-4 \mu \mathrm{m}$ decreases. Finally, there is a third porosity zone around $10 \mu \mathrm{m}$, but with greater scatter (varying from 5 to $20 \mu \mathrm{m}$ ) according to the samples.

Irradiated samples from two reactors and with different neutron flux or temperatures were characterised, as were unirradiated samples. Generally speaking, irradiation leads to a relatively minor change in the characteristics of the graphite, the average wear being less than $5 \%$, although it reaches close to $8 \%$ locally. Overall, a decrease in the density could be observed, associated with an increase in open porosity mainly in the macroporous domain. The results are not significant enough to distinguish any general variations in closed porosity. These changes in the characteristics are associated with the radiolytic corrosion of graphite, corrosion which is all the greater when the samples are subjected to high fluences and irradiation temperatures. 


\section{Journal of Nuclear Materials}

\author{
Part 2 - Water up-take
}

\section{Unirradiated samples}

The water uptake kinetics for unirradiated samples are presented in Figure 8. It can be seen that the water uptake kinetics are slower for the G2 samples than for the SLA2 samples. Moreover, only less than half of the total open porosity, even after more than 700 days of impregnation, was filled for the G2 samples. Unirradiated SLA2 graphite presents a slightly different behaviour. The water impregnation rate is faster but, at the end, water uptake seems to be limited to around $70 \%$ of the total porosity. The water impregnation kinetics for the two types of graphite were relatively high during the first phase lasting about 150 days and then they slowed down dramatically.

A connection can be established between these two steps of the impregnation process and the pore distribution of nuclear graphite using mercury intrusion porometry. The first rapid-filling step relates to the filling of the macroporosity that represents $65 \%$ of the total open porosity in the case of the SLA2 graphite samples (35\% of the pores are in the mesoporosity domain pore diameter between 1 and $300 \mathrm{~nm}$ ). For G2 graphite, the water does not fill all the macroporosity of the sample. This difference cannot only be attributed to the diameter of the pores but also to the hydrophobic phenomena. To check this assumption, some complementary experiments were performed in an ethanol-water mixture. Adding ethanol (10 wt $\%)$ improves impregnation: the kinetics and saturation rate increased significantly. Adding ethanol to water helps lower the surface tension (Table 9) of the mixture and therefore promotes its impregnation in a hydrophobic solid.

\begin{tabular}{|c|c|}
\hline Solution & Surface tension $(\mathrm{mN} / \mathrm{m})$ \\
\hline Water & 72.8 \\
\hline Ethanol & 22 \\
\hline Water+10\% wt Ethanol & 52 \\
\hline
\end{tabular}

TABLE 9: SURFACE TENSION AT $20^{\circ} \mathrm{C}$ 


\section{Journal of Nuclear Materials}

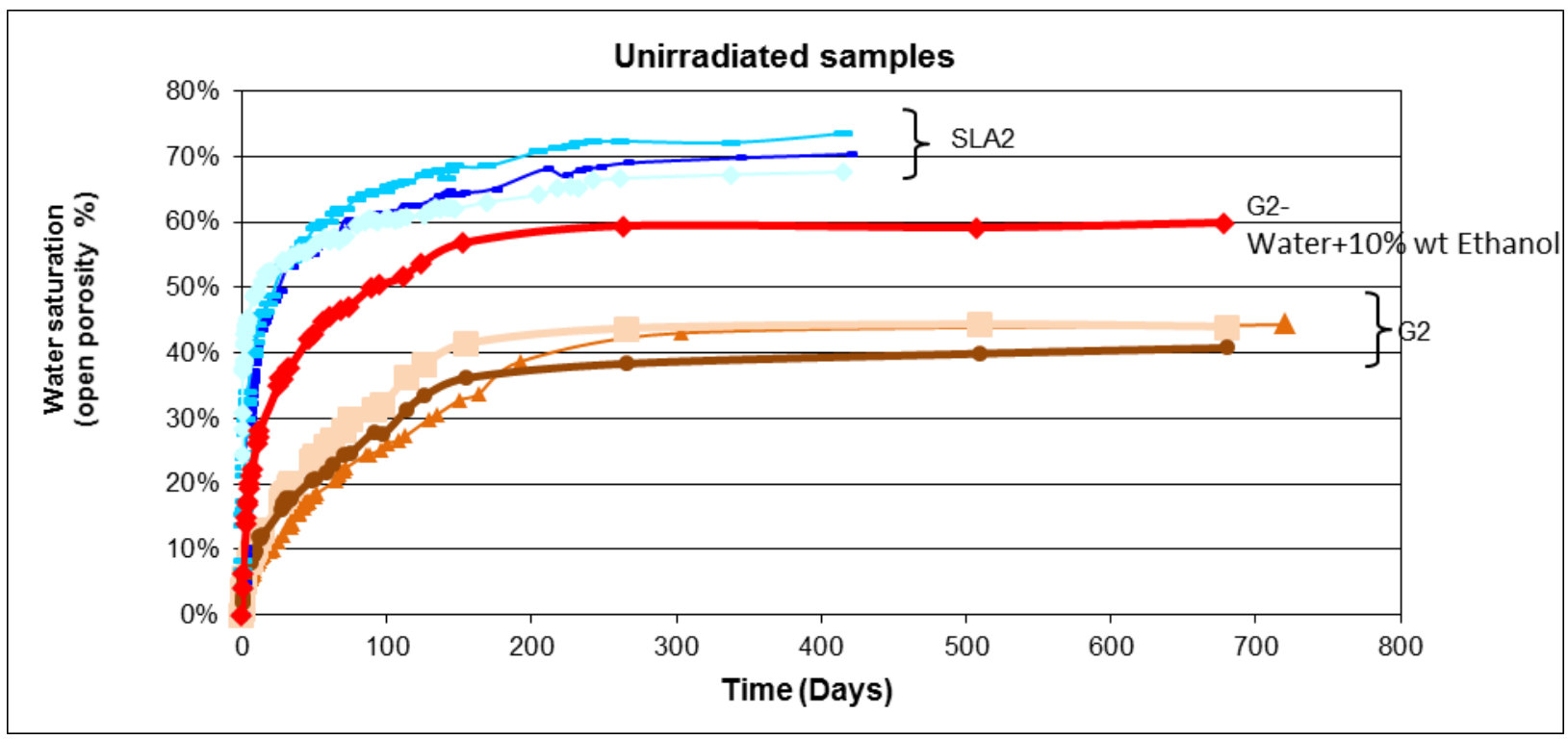

FIGURE 8 : COMPARISON OF WATER AND WATER-ETHANOL IMPREGNATION RATES FOR UNIRRADIATED STACK GRAPHITE FROM THE G2/SLA2 REACTORS

Considering the uncertainty on the measurement of the sample volumes, open porosities and mass gains, a relative uncertainty of $10 \%$ was attributed

In the ethanol-water mixture, water uptake in the G2 samples is faster as illustrated in Figure 9 versus the square root of time, and the saturation of the open porosity increases from $40 \%$ to $60 \%$.



\section{FIGURE 9: COMPARISON OF WATER AND WATER-ETHANOL IMPREGNATION RATES FOR UNIRRADIATED STACK GRAPHITE FROM THE G2/SLA2 REACTORS}

To conclude, the water uptake in unirradiated graphite not only depends on the pore size distribution, but also on the initial surface state. 


\section{Journal of Nuclear Materials}

\section{Irradiated samples}

The results obtained on irradiated graphite are presented in Figure 10 for G2 and Figure 11 for SLA2.

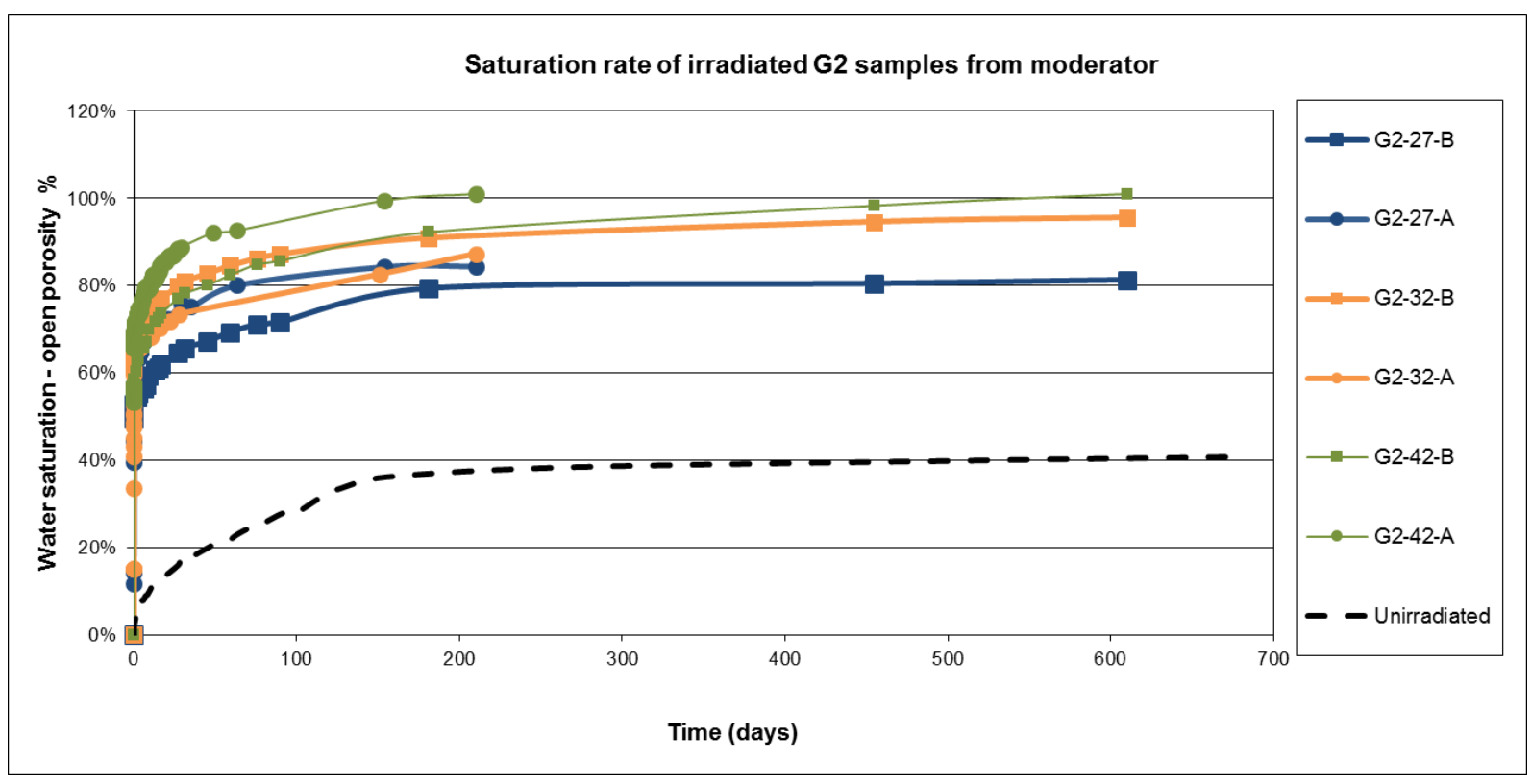

\section{FIGURE 10: SATURATION RATE OF IRRADIATED G2 SAMPLES FROM THE MODERATOR}

Considering the uncertainty on the measurement of the sample volumes, open porosities and mass gains, a relative uncertainty of $10 \%$ was attributed

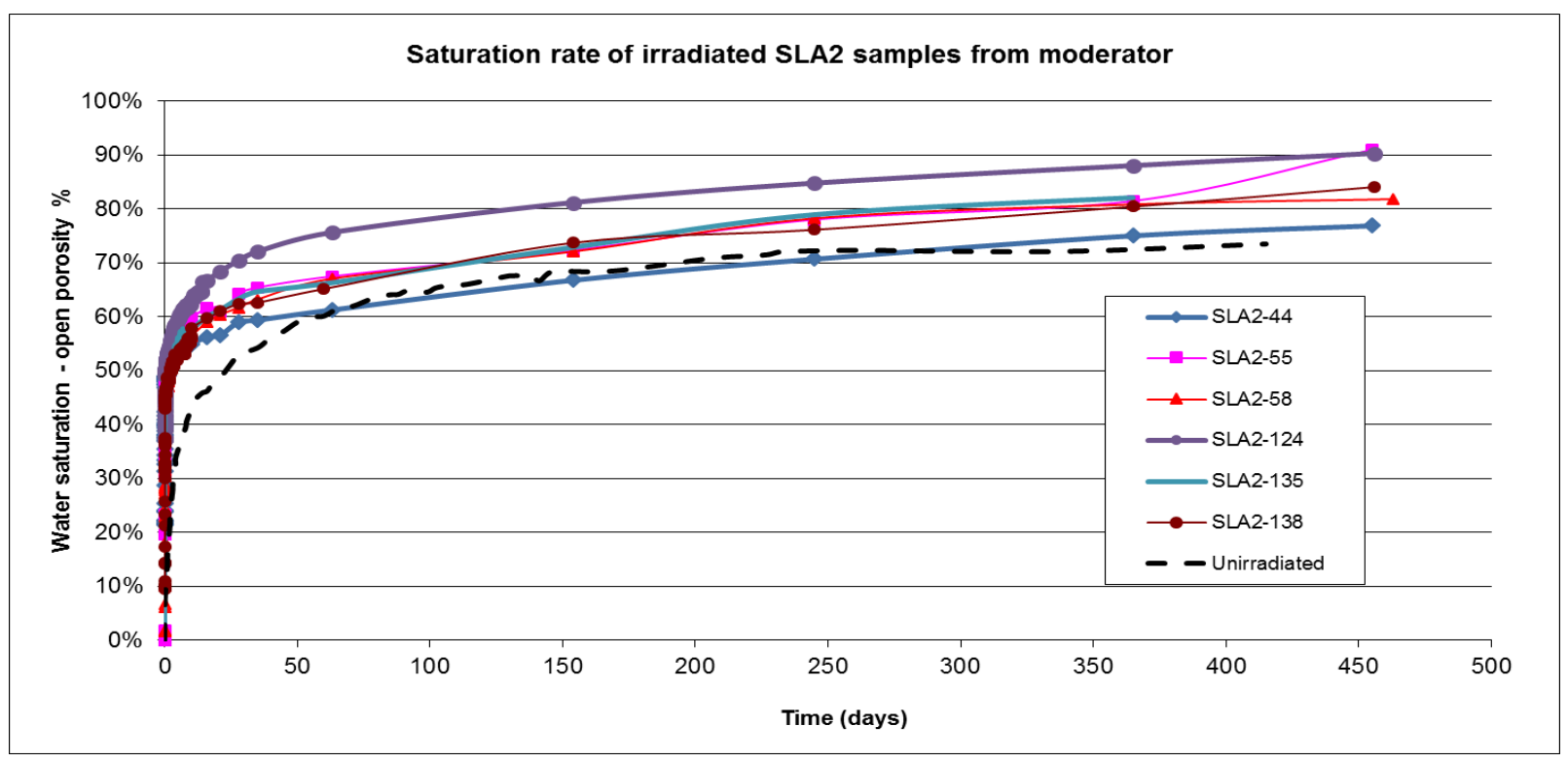

FIGURE 11: SATURATION RATE OF IRRADIATED SLA2 SAMPLES FROM THE MODERATOR

Considering the uncertainty on the measurement of the sample volumes, open porosities and mass gains, a relative uncertainty of $10 \%$ was attributed 


\section{Journal of Nuclear Materials}

These differences between nuclear graphite from different origins are reduced when considering irradiated samples. Irradiated graphite is a more hydrophilic material than the unirradiated one. It is evidenced in Figure 10 that the porosity is rapidly filled in the first 30 to 50 days and then this slows down to reach $75 \%$ to around $100 \%$ of the open porosity.

At the same time, the curve in Figure 10 shows that the difference in size between the G2 samples does not seem to modify the total rate of open porosity, but only the water impregnation kinetics.

These results show that irradiation increases the water impregnation kinetics and the saturation rate of the graphite. The original behaviour of unirradiated graphite is completely erased by the irradiation time in the reactor. Two reasons can explain this difference:

- First, irradiation modifies the macroporosity of the different types of graphite, particularly by widening the mean pore diameter as shown in the mercury intrusion porosimetry spectrums, which may facilitate water impregnation. Irradiated graphite was mainly a macroporous solid (about $80 \%$ of the total porosity with an apparent pore diameter ranging between 1 and $30 \mu \mathrm{m}$ ).

- Second, it is known that irradiation and radiolytic corrosion result in breaking the C-C bonds in the graphite crystallites and/or grain boundaries to form more hydrophilic $\mathrm{C}$ $\mathrm{H}$ or $\mathrm{C}-\mathrm{O}$ bonds at the surface.

These two phenomena lead to faster and higher impregnation. 


\section{Journal of Nuclear Materials}

\section{Conclusion}

In the framework of the studies on the disposal of graphite waste from UNGG reactors, it is necessary to obtain reliable data on the behaviour of long-lived radionuclides when graphite will be water-saturated in disposal conditions. Water impregnation in irradiated graphite is the first step of a process that leads to the release of radionuclides contained in the graphite. If this step is slow and low, it can control both the kinetics and the release rate of radionuclides in solution. Impregnation tests were therefore performed on unirradiated and irradiated graphite samples from the G2 and St Laurent A2 reactors which had been previously characterised by geometric density measurements, He pycnometry and $\mathrm{Hg}$ porosimetry.

Characterisation of the structural (or microstructural) properties and the water uptake experiments of unirradiated graphite made it possible to determine that they do not have the same pore size distribution and most probably have a different surface effect depending on their origin. The SLA2 graphite was seen to have two types of porous distribution, i.e. around $35 \%$ of pores in the mesoporous domain (pore diameter between 1 and $300 \mathrm{~nm}$ ) and $40 \%$ of the total porosity in the macroporous zone (pore diameter between 1-5 $\mu \mathrm{m}$ ). G2 graphite presents a quasi-single macroporous distribution. Moreover, SLA2 graphite appears to be more hydrophilic than $\mathrm{G} 2$ graphite.

In general, irradiation induces a small modification in the characteristics of graphite. In both cases, it appears that the geometric density of the samples decreases under irradiation, which is expressed as an increase in total porosity, more precisely in the open porosity. The pore size in the macroporous domain increases (total fraction and average diameter), whereas the mesoporous fraction does not seem to be affected by irradiation. This variation appears to be correlated with the neutron flux. This is a consequence of radiolytic corrosion of the graphite under $\mathrm{CO}_{2}$ irradiation. Results from water uptake experiments show that the graphite becomes more hydrophilic after irradiation. The original behaviour of unirradiated graphite seems to be completely erased by their time in the reactor. This is probably due to the combined effects of temperature and irradiation, which lead to radiolytic corrosion of graphite and the presence of functional groups on the surface, which seems to modify the surface tension. The impregnation kinetics are faster and the saturation rate is close to $100 \%$ with regard to open porosity.

Considering the leaching behaviour of radionuclides in nuclear graphite under disposal conditions, these results show that the open porosity can be considered as being filled with water in a hundred days. Water penetration can be considered as a limiting factor for the most mobile radionuclides (leaching under $<100$ days), but not for the non-mobile radionuclides. Moreover, the porosity of irradiated graphite in storage conditions will be saturated by the water site which is alkaline water. A possible chemical degradation in the surface compounds by this aggressive media is to be considered. 


\section{Journal of Nuclear Materials}

\section{Acknowledgements}

510 This work was carried out under the CARBOWASTE Programme: Treatment and Disposal of

511 Irradiated Graphite and Other Carbonaceous Waste (Grant Agreement number FP7-211333),

512 with partial funding from ANDRA, EDF and the CEA. The authors would also like to thank

513 those in charge of G2 or EDF reactor operations and dismantling for having provided these

514 samples and Mr Laurent Petit, EDF, for his assistance and follow-up of these studies. 


\section{Journal of Nuclear Materials}

1 Banford, A.W., Eccles, H., \& Ross, D. Strategic Options for the Management of Waste Irradiated Graphite. 2009 Waste Management Symposium - WM2009/WM'09: HLW, TRU, LLW/ILW, Mixed, Hazardous Wastes and Environmental Management - Waste Management for the Nuclear Renaissance, United States

2 ANDRA, Inventaire national des matières et déchets radioactifs, http://www.andra.fr/inventaire2012/04_pdf_documents/03-Andra-2012-familles.pdf

3 Planning act of the French parliament No. 2006-739, 28 June 2006, http://www.legifrance.gouv.fr/affichTexte.do?cidTexte=JORFTEXT000000240700

4 A Kozbial , F Zhou, Z Li, H Liu, Li L. Are Graphitic Surfaces Hydrophobic? Acc Chem Res. 2016 Dec 20;49 (12): 2765-2773.

5 J Bonal, J.P., Robin, J.C.,. Les réacteurs nucléaires à caloporteur gaz. CEA 2006 Monography 27-32.

6 P. Cornuault, Génie nucléaire, modérateurs, graphite, Société des Electrodes Réfractaires Savoie, first ed., 1981

7 Characterisation, Treatment and Conditioning of Radioactive Graphite from Decommissioning of Nuclear Reactors, first ed., IAEA TECDOC 1521, Austria, September 2006.

8 Irradiation damage in graphite due to fast neutron in fission and fusion systems IAEA TECDIC-1154, Vienna 2000

9 J Rappeneau, M Bocquet, G Micaud, A Fillatre. Effets de l'irradiation sur les propriétés physiques du graphite Carbon 1964, VoI. 1, pp. 97-109

10 B. J. Marsden, M. Haverty, W. Bodel, G. N. Hall, A. N. Jones, P. M. Mummery \& M. Treifi, Dimensional change, irradiation creep and thermal/mechanical property changes in nuclear graphite, International Materials Reviews, 2016, 61:3, 155-182, DOI: 10.1080/09506608.2015.1136460

11 T.D. Burchell, P.J. Pappano, J.P. Strizak, A study of the annealing behavior of neutron irradiated graphite, Carbon 49, 2011, 3-10.

12 Kelly, B.T.,Graphite - the most fascinating nuclear material.. Carbon 20, 1982, 3-11.

13 Wickham, A. J., J. V. Best, et al. Recent advances in the theories of carbon dioxide radiolysis and radiolytic graphite corrosion. Radiation Physics and Chemistry, 1977, 10(2): 107-117.

14 P.J. Heard, L. Payne, M.R. Wootton, P.E.J. Flewitt, Evaluation of surface deposits on the channel wall of trepanned reactor core graphite samples, J. Nucl. Mater. 445 (1-3) 2014 pp91-97

15 International Atomic Energy Agency, Vienna (Austria). International Working Group on Gas-Cooled Reactors; p. 125-131; May 1981; p. 125-131; Specialists meeting on coolant 


\section{Journal of Nuclear Materials}

chemistry, plate-out and decontamination in gas-cooled reactors; Juelich, Germany, F.R; 2 - 4 Dec 1980 http://www.iaea.org/inis/collection/

16 J.L. Figueiredo, M.F.R. Pereira, M.M.A. Freitas, J.J.M. Orfao, Modification of the surface chemistry of activated carbons, Carbon, 37, 1999, pp. 1379-1389.

17 J.V. Best, W.J. Stephen, A.J. Wickham, Radiolytic graphite oxidation, Prog Nucl Energy,16 (2),1985, , pp. 127-178

18 D. LaBrier, M.L. Dunzik-Gougar Characterization of C-14 in neutron irradiated NBG-25 nuclear graphite, J. Nucl. Mater., 448, 2014, pp. 113-120

19 T.E. Smith, S. Mccrory, M.L. Dunzik-Gougar Limited oxidation of irradiated graphite waste to remove surface carbon-14, Nucl. Eng. Techn., 45, 2013, pp. 211-218

20 Horowitz P., Bussac, Joatton, De Lagge de Meux, Martin Caractéristiques générales et aspects originaux des réacteurs G2 et G3, 1958, Rapport CEA R-951, / http://www.iaea.org/inis/collection/

21 Herreng M, Ertaud et Pasquet Description des réacteurs G2 - G3, 1958 Rapport CEA R952, http://www.iaea.org/inis/collection/

22 Leo M, et Maillard M Réacteurs nucléaires, 1960, Rapport CEA R-1659, http://www.iaea.org/inis/collection/

23 D. Bastien, Réacteurs à uranium naturel graphite-gaz (Uranium Natural Graphite-Gas reactors), Techniques de l'Ingénieur B 3180, 1993

24 Zhengcao Li, Dongyue Chen, Xiaogang Fu, Wei Miao, and Zhengjun Zhang, The Influence of Pores on Irradiation Property of Selected Nuclear Graphites Advances in Materials Science and Engineering, vol. 2012, Article ID 640462, 6 pages, 2012. doi:10.1155/2012/640462 